Board of Governors of the Federal Reserve System

International Finance Discussion Papers

Number 1291

October 2020

\title{
Natural Disasters, Climate Change, and Sovereign Risk
}

\author{
Enrico Mallucci
}

Please cite this paper as:

Mallucci, Enrico (2020). "Natural Disasters, Climate Change, and Sovereign Risk," International Finance Discussion Papers 1291r1. Washington: Board of Governors of the Federal Reserve System, https://doi.org/10.17016/IFDP.2020.1291r1.

NOTE: International Finance Discussion Papers (IFDPs) are preliminary materials circulated to stimulate discussion and critical comment. The analysis and conclusions set forth are those of the authors and do not indicate concurrence by other members of the research staff or the Board of Governors. References in publications to the International Finance Discussion Papers Series (other than acknowledgement) should be cleared with the author(s) to protect the tentative character of these papers. Recent IFDPs are available on the Web at www.federalreserve.gov/pubs/ifdp/. This paper can be downloaded without charge from the Social Science Research Network electronic library at www.ssrn.com. 


\title{
Natural Disasters, Climate Change, and Sovereign Risk
}

\author{
Enrico Mallucci*
}

\begin{abstract}
I investigate how natural disasters can exacerbate fiscal vulnerabilities and trigger sovereign defaults. I extend a standard sovereign default model to include disaster risk and calibrate it to a sample of seven Caribbean countries that are frequently hit by hurricanes. I find that disaster risk reduces government's ability to issue debt and that climate change further restricts government's access to financial markets. Next, I show that "disaster clauses", that provide debt-servicing relief, allow governments to borrow more and preserve government's access to financial markets, amid rising risk of disasters. Yet, debt limits may need to be adopted to avoid overborrowing and a decline of welfare.
\end{abstract}

JEL classification: F32, F34, Q54.

Keywords: Sovereign risk, climate change, natural disasters.

\footnotetext{
${ }^{*}$ Board of Governors of the Federal Reserve System, Washington, D.C. 20551 U.S.A.. E-mail: enrico.mallucci@frb.gov. I thank Aitor Erce and Mattia Picarelli, as our ongoing effort to document domestic default episodes sparked the idea for this project. I also thank Tamon Asonuma and Sergio de Ferra for comments and suggestion. The views in this paper are solely the responsibility of the author and should not be interpreted as representing the views of the Board of Governors of the Federal Reserve System or any other person associated with the Federal Reserve System.
} 


\section{Introduction}

Unexpected shocks may tip vulnerable countries in a default. While the literature has emphasized the role of macroeconomic and financial shocks, such as a decline of commodity prices (Reinhart et al., 2016) or banking crises (Balteanu and Erce, 2018), in shaping sovereign risk, non-economic shocks, such as political events or extreme weather, are equally important. ${ }^{1}$ Extreme weather appears especially salient in light of the key role played by natural disasters in recent default episodes (i.e. Grenada 2004, Antigua y Barbuda 2004 and 2009), the climate crisis, and the ongoing debate around climate-change adaption strategies. In particular, the increasing frequency and intensity of natural disasters, such as hurricanes and tropical storms, has led economists and policy makers to advocate in favor of "disaster clauses", that allow for a temporary debt moratorium when countries are hit by disasters. Using a quantitative model of sovereign default, I study the impact of extreme weather and climate change on governments' access to financial markets showing that they reduce governments' ability to borrow from abroad. Additionally, I show that "disaster clauses", that allow governments to suspend debt servicing when disaster hits, allow governments to borrow more and preserve their access to financial markets, amid increasing risk of natural disasters. That said, debt limits may need to be adopted in conjunction with disaster clauses to avoid excessive borrowing and a decline of welfare.

To quantify the impact of extreme weather and climate change on sovereign risk, I introduce disaster risk in an otherwise standard sovereign default model with long-term bonds as in Hatchondo and Martinez (2009). Disasters take the form of exogenous shocks to income and are calibrated to reproduce the frequency and the intensity of major hurricanes in a sample of seven Caribbean economies that are the focus of this study. In the quantitative analysis, I show that the model matches well key moments in the data. When I compare model prediction in the baseline model with model predictions in an alternative version of the model that eliminates disaster risk, I find that extreme weather restricts government's access to financial markets: Absent disaster risk, governments borrow more.

Next, I evaluate the impact of climate change on public finances, investigating how government policies respond to an increase of the frequency and the intensity of hurricanes. I find that governments face worse borrowing conditions when extreme weather events become more frequent and intense. As a result, governments issue less debt and the debt-to-GDP ratios decline.

Finally, I analyze the impact on governments' access to financial market of disaster clauses that allow government to stop servicing debt when disaster hit. I find that such clauses facilitate market access allowing governments to borrow at better rates. Yet, they also induce governments to borrow more. On net, governments expand their borrowings so much that spreads increase. To investigate the impact of disaster clauses on welfare, I compute

\footnotetext{
${ }^{1}$ The ongoing COVID-19 pandemic is also an example of a non-economic shock that may exacerbate existing fiscal weaknesses as highlighted by the recent work of Arellano et al. (2020).
} 
consumption equivalents that make agents indifferent between the baseline economy and the economy with disaster clauses. I find that debt limits may be needed together with disaster clauses to avoid excessive borrowings and a decline of welfare.

My paper contributes to two main strands of the literature. First and foremost, I contribute to the quantitative literature on sovereign risk in the tradition of Eaton and Gersovitz (1981) and Arellano (2008). In particular, this paper highlights and quantify the impact of natural disasters and climate change on sovereign risk. In doing so, this paper also stresses the importance of non-economic shocks and disaster events in explaining default risk. ${ }^{2}$ Closely related, Rebelo et al. (2018) examine the relation between rare financial disasters, financial development, and sovereign risk and find that rare financial disasters restrict governments' ability to issue debt in countries with low financial development. This paper shares a similar message in that it shows that natural disasters and climate change may also reduce governments' ability to borrow from abroad. In an independent working paper with an analytical focus Phan and Schwartzman (2020) also examine the effects of natural disasters on sovereign debt models. While the two papers share the same interest for the interaction between natural disasters and sovereign risk, they differ in that this paper has a quantitative focus. Specifically, I quantify the impact of hurricanes and climate change on key economic variables, such as sovereign spreads, debt-to-GDP levels, and welfare, in a sample of seven Caribbean economies.

Second, I contribute to the literature that quantifies the impact of disaster risk on asset prices (Barro, 2009) and the macroeconomy (Gourio, 2012). In particular, this paper is related to the work of Mejia (2016) and Nordhaus (2010) that estimate the economic cost of hurricanes in the Caribbean and in the United States and their projected evolution with climate change. ${ }^{3}$ This paper pushes this line of research further, as it evaluates the implications of such costs for public finances, the price of government debt, and sovereign risk.

The rest of the paper is organized as follows. Section 2 presents background information on the interaction between sovereign risk and extreme weather with a special emphasis on Grenada. Section 3 introduces the theoretical model. Section 4 presents the calibration strategy for the quantitative analysis. Section 5 reports quantitative results. Section 6 examines disaster clauses analyzing their quantitative implications and showing that debt limits may be needed in conjunction with disaster clauses to improve welfare. Finally, section 7 concludes.

\footnotetext{
${ }^{2}$ Hatchondo and Martinez (2010) and Alessandria et al. (2019) also investigate the role of non-economic factors in shaping default risk, focusing on political risk and migration.

${ }^{3}$ Other related papers are Belasen and Polachek (2008) focusing on the impact of hurricanes on wages and employment; Deryugina et al. (2018) and Gallagher and Hartley (2017) focusing on the impact of hurricanes on household income and finances; and Roth Tran and Wilson (2019) focusing on impact of hurricanes on local economies.
} 


\section{Sovereign Defaults and Natural Disasters: Recent Evidence}

An inspection of recent default episodes shows that extreme weather has often played a prominent role, especially in small agricultural countries where extreme weather events affect a vast portion of the territory. ${ }^{4}$ Moldova, Suriname, and Ecuador offer three neat examples of the nexus between sovereign risk and natural disaster. Moldova and Suriname defaulted respectively in 1992 and 1998 following severe droughts that weakened the production of agricultural export goods (International Monetary Fund, 1999b; Vos et al., 2000). Ecuador defaulted in 1997 just a few months after floods caused major power shortages (Sturzenegger and Zettelmeyer, 2007).

The nexus between sovereign vulnerabilities and natural disasters is especially visible in Caribbean countries, which are the main focus of this paper. Caribbean countries are vulnerable to natural disasters as they are small and are hit regularly by hurricanes and tropical storms. ${ }^{5}$ The cases of the Dominican Republic, Antigua y Barbuda, and Grenada are worth highlighting. On September 22 1998, the Dominican Republic was hit by hurricane Georges. The devastation brought by the hurricane and the damages to the economy were so extensive that the Dominican government had to seek support from the IMF and other official lenders in that very same year (International Monetary Fund, 1999a). Antigua y Barbuda shares a similar story. Following a series of hurricanes in the late '90s, the government began to accumulate arrears and ultimately defaulted. Finally, the case of Grenada is emblematic. Between 1999 and 2002, Grenada's fiscal position deteriorated sharply and the debt-to-GDP ratio increased from about 35\% to 80\% (Asonuma et al., 2018). Grenada's fiscal position ultimately became unsustainable when hurricane Ivan hit the island in September 2004, causing damages estimated at $\$ 900$ million, equivalent to about $150 \%$ of Grenada's GDP. Tourism and agriculture, the two major sources of export earnings, were especially hit, as the hurricane damaged infrastructure and wiped out the entire nutmeg crop. By the end of 2004, Grenada debt-to-GDP ratio stood at 130\%, forcing the government to restructure its debt.

Sovereign risk and natural disasters are so interwoven in the Caribbean that governments have started to introduce bonds featuring disaster clauses. Such clauses aim to provide liquidity relief during catastrophic events, as they allow governments to suspend debt servicing payments. The government of Grenada led the way. In 2013, Grenada's debt was restructured for the second time in a decade to address underlying solvency problem. A key feature of the restructuring event is that new bonds included a hurricane clause, allowing governments to delay debt servicing for up to one year in the event of a hurricane causing damages exceeding US $\$ 15$ million. Grenada's decision to introduce a hurricane clause was

\footnotetext{
${ }^{4}$ Countries,such as Thailand and Indonesia, in which the economic activity is highly concentrated in areas that are prone to extreme weather are also at risk of natural disasters.

${ }^{5}$ Table 7 in the Appendix reports the chronology of major hurricane hits in a sample of 7 Caribbean countries.
} 
endorsed by the Paris Club and other countries, including Mexico and Barbados, have now followed Grenada's example. More broadly, the introduction of disaster clauses has been gaining support among policy makers, especially in light of IMF's emphasis on incorporating natural disaster risk as a component of macroeconomic risk management.

\section{Model}

In this section, I present the workhorse model that I adopt to study the impact of extreme weather and climate change on sovereign risk. The model extends the baseline quantitative sovereign default model of Arellano (2008) to include long-term bonds, as in Hatchondo and Martinez (2009), and disaster risk. Long-term bonds are introduced to improve the quantitative performance of the model and allow the model to replicate both the debt-toGDP ratios and the sovereign spreads observed in the data. Disaster risk is introduced to replicate the impact of major hurricanes on GDP and is modeled as an exogenous shock to the income process.

The world economy is composed of one small open economy and international lenders. The small open economy is inhabited by a continuum of identical risk-averse households and by a government. Households receive an exogenous stream of income $y$ and are subject to a disaster shock $h$. The government is benevolent and maximizes the welfare of the representative household.

The choice problem of the government is identical to the one presented in Hatchondo and Martinez (2009). ${ }^{6}$ When the government has access to international financial markets, it can default on external debt or repay. If it defaults, the government loses access to financial markets. If it repays, the government decides on the amount of assets to issue in the current period. Crucially, the government borrows using long-term bonds that promise an infinite stream of coupons, which decreases at a constant rate $\psi{ }^{7}$ The state variables of the model economy are the stock of outstanding coupon claims $b$, the realization of the endowment process $y$, and the realization of the disaster shock $h$.

Government's optimal default decision $d$, conditional on the country having access to the financial market, solves

$$
V=\max _{d}\left\{(1-d) V^{n d}+d V^{d}\right\}
$$

Where $V^{n d}$ and $V^{d}$ are household's value functions in the non-default and in the default scenarios and where $d$ is an indicator taking the value of one when the government decides to default.

\footnotetext{
${ }^{6}$ I briefly describe here the key equations of the model. Refer to the original paper for a more thorough treatment.

${ }^{7}$ As in Hatchondo and Martinez (2009), the duration of the government bonds is defined as $D=\frac{1+r^{*}}{r^{*}+\psi}$
} 
The value function $V^{n d}$ is the solution to the following maximization problem:

$$
\begin{gathered}
V^{n d}(y, h, b,)=\max _{c, b^{\prime}} u(c)+\beta \mathbb{E}\left[V\left(y^{\prime}, h^{\prime}, b^{\prime}\right)\right] \\
\text { s.t. } c=y+q\left[b^{\prime}-(1-\psi) b\right]-b, \\
q\left(y^{\prime}, h^{\prime}, b^{\prime}\right)=\frac{1}{\left(1+r^{f}\right)} E\left[\left(1-d^{\prime}\right)+(1-\psi)\left(1-d^{\prime}\right) q^{\prime}\right] .
\end{gathered}
$$

Equation (4) is the asset pricing equation of government bonds and is included in the set of constraint, as the government has monopoly power over the amount of government debt. Equation (3) is the resource constraint of the model economy and states that consumption equals income plus net imports from abroad. The income process follows a log-normal AR(1) process which is subject to two shocks. A standard endowment shock that captures business cycle fluctuations, and a rare event disaster shock $h \mathcal{N}\left(\mu_{h}, \sigma_{h}\right)$, that affects the economy with probability $p_{h}$ and is meant to capture hurricane hits. The income process reads:

$$
\log \left(y^{\prime}\right)=\rho \log (y)-\xi h+\epsilon^{y}
$$

Where $\xi$ is an indicator function that is equal to one when the economy is hit by a hurricane and $\epsilon^{y} \sim \mathcal{N}\left(0, \sigma_{y}\right)$ is the endowment shock. Of note, hurricane shocks affect income for multiple periods through the autoregressive component $\rho \log (y)$ of the income process. ${ }^{8}$

If the government chooses to default, or lacks access to financial markets, the economy suffers an output cost of exclusion. In this setting, the country's endowment is reduced to $\delta(y)$, where $\delta(y) \leq y$. The government can re-gain access to financial markets with the exogenous probability $\lambda$. The value function in case of default is:

$$
\begin{gathered}
V^{d}(y, h, 0)=u(c)+\beta \mathbb{E}\left[(1-\lambda) V^{d}\left(y^{\prime}, h^{\prime}, 0\right)+\lambda V\left(y^{\prime}, h^{\prime}, 0\right)\right] \\
\text { s.t. } c=\delta(y),
\end{gathered}
$$

where equation (7) is the resource constraint of the economy under autarky.

\subsection{International Investors}

As it is standard in the sovereign default literature, it is assumed that international investors are risk neutral and have deep pockets. They purchase government bonds and have access

\footnotetext{
${ }^{8}$ Disaster risk is modeled in the form of an exogenous shocks, as it goes beyond the scope of the paper to explain how hurricanes reduce income. The main objective of the paper is to study how hurricane risk affects governments' borrowing and default decisions, taking the impact of hurricane risk on output as given.
} 
to a risk-free asset that pays the return $r^{r f}$. The price of government bonds is determined by arbitrage:

$$
q\left(y^{\prime}, h^{\prime}, b^{\prime}\right)=\frac{1}{\left(1+r^{f}\right)} E\left[\left(1-d^{\prime}-r e l^{\prime}\right)+(1-\psi)\left(1-d^{\prime}-r e l^{\prime}\right) q^{\prime}\right] .
$$

The first term on the right-hand side of equation (8) is the next-period coupon payment promised in a bond. The second term in the right-hand side is the expected value of all other future coupon payments, which is summarized by the expected price at which the bond could be sold next period. The hurricane shock together with the endowment shock and the debt level determine the price of government bonds. ${ }^{9}$

\section{Calibration and Functional Forms}

The model is calibrated to reproduce the quantitative properties of a set of Caribbean countries-Antigua y Barbuda, Belize, Dominica, the Dominican Republic, Grenada, Honduras, and Jamaica-from 1980 to 2019, at the annual frequency. ${ }^{10}$ Households' utility function takes the standard constant relative risk aversion (CRRA) form:

$$
U(c)=\frac{c^{1-\gamma}}{1-\gamma},
$$

where the parameter $\gamma$ determines the degree of risk aversion.

Following Arellano (2008), I assume that output costs of default are asymmetric and increasing in the endowment realization in a piecewise-linear fashion: ${ }^{11}$

$$
\delta(y)=\left\{\begin{array}{ll}
y & \text { if } y \leq \delta E(y) \\
\delta E(y) & \text { if } y>\delta E(y)
\end{array} .\right.
$$

Table 1, reports parameter values that are used in the calibration exercise. Panel A reports standard parameters that are the calibrated to the same value for each country. The riskaversion parameter $\gamma$ is set equal to 2 as it is standard in the literature. The re-entry probability parameter $\lambda$ is set equal to 0.33 which is consistent with the average re-entry time found in Richmond and Dias (2009). Finally, risk-free rate is set equal to 0.0451 to replicate the average annual T-Bill rate from 1980 to 2019.

\footnotetext{
${ }^{9}$ The formal definition of the model equilibrium is reported in the appendix.

${ }^{10}$ Data at the quarterly frequency are only sparsely available for some Caribbean countries.

${ }^{11}$ Arellano (2008) shows that asymmetric default costs are crucial for the model to deliver a realistic debtto-GDP ratio. In this model the expected value of the endowment is computed taking into account the probability of hurricane hits.
} 
Panel B reports parameters that are calibrated to different values for each of the seven countries. Parameters above the line are calibrated independently. Parameters $\beta$ and $\delta$ below the line are jointly determined using the method of moments and targeting simultaneously the average spread between the US T-Bills and the corresponding bond in each country as well as the average debt-to-GDP ratio. ${ }^{12}$ Parameter $\psi$ is chosen to replicate the average duration of government bonds in each of the seven countries I analyze. ${ }^{13}$

Parameter $p_{h}$ is set equal to the annual frequency of major hurricane hits in each of the seven countries since 1980, as reported by the National Oceanic and Atmospheric Administration (NOAA). Table 7 in the Appendix reports the chronology of major hurricane hits since 1871. ${ }^{14}$ Antigua y Barbuda and Jamaica are the two countries that are most frequently hit by hurricanes in our sample, as they are hit by major hurricanes every 9.7 years. On the opposite side of the spectrum, Dominica has only been hit once by hurricanes in the last 39 years. $^{15}$

Parameters $\rho, \sigma_{y}, \mu_{h}$, and $\sigma_{h}$ are estimated regressing equation (5) using logged and detrended GDP data from 1980 to 2019 for each country. Parameter $\rho$ is set equal to the point estimate of the coefficient of lagged GDP. Parameter $\sigma_{y}$ is set equal to the standard deviation of the regression errors. Parameter $\mu_{h}$ is set equal to the regression coefficient for the dummy variable of hurricane hits. Finally, parameter $\sigma_{h}$ is set equal to the standard deviation of the coefficient of the dummy variable. ${ }^{16}$

\footnotetext{
${ }^{12}$ For Antigua y Barbuda, Dominica, Grenada, and Jamaica I use the spread between 3-months T-Bills and the corresponding 3-months US T-Bills. For Dominican Republic and Honduras I use the EMBI spread. For Belize I use the spread between 1-year T-Bill and the corresponding 1-year T-Bill.

${ }^{13}$ The average maturity of government debt of Belize, Dominica, Dominican Republic, and Grenada are taken from Schumacher et al. (2020). The average maturity for government debt in Antigua y Barbados and Jamaica are taken from the "Medium-Term Debt Management Strategy" of each country. Finally, the average maturity of government debt in Honduras is taken from the IADB's "Maturity Profile of Internal and External Debt" database.

${ }^{14}$ Major hurricanes are those classified category three or higher.

${ }^{15}$ As the calibration is annual, I do not need to account for the seasonal nature of hurricanes.

${ }^{16}$ Years in which countries were excluded from financial markets were excluded from the sample. For Granada, GNI, which is believed to be a more accurate measure of wealth creation for small countries, is used. GDP and GNI data come from the World Bank database.
} 
Table 1. Calibration

\begin{tabular}{lccc}
\hline \hline \multicolumn{3}{c}{ Panel A: Common Parameters } \\
Moment & Value & Source/Target Statistic \\
\hline \hline Relative risk aversion & $\gamma$ & 2 & Standard \\
Readmission probability & $\lambda$ & 0.33 & Richmond and Dias (2009) \\
Rik free rate & $r^{f}$ & 0.0451 & US T-Bill \\
\hline \hline
\end{tabular}

Panel B: Country-Specific Parameters

\begin{tabular}{|c|c|c|c|c|c|c|c|c|c|}
\hline Moment & & Antigua & Belize & Dominica & Dominican Rep. & Grenada & Honduras & Jamaica & Source/Target \\
\hline Duration & $\psi$ & 0.0824 & 0.0442 & 0.0467 & 0.1731 & 0.0612 & 0.1639 & 0.0564 & Average Maturity \\
\hline Hurricane freq. & $p_{h}$ & 0.103 & 0.077 & 0.026 & 0.051 & 0.051 & 0.051 & 0.103 & NOAA \\
\hline Endowment autocorr. & $\rho_{y}$ & 0.92 & 0.99 & 0.94 & 0.88 & 0.91 & 0.83 & 0.96 & GDP/GNI World Bank \\
\hline Endowment st. dev. & $\sigma_{y}$ & 0.046 & 0.036 & 0.027 & 0.046 & 0.052 & 0.026 & 0.026 & GDP/GNI World Bank \\
\hline Hurricane mean loss & $\mu_{h}$ & 0.049 & 0.021 & 0.098 & 0.040 & 0.070 & 0.052 & 0.023 & GDP/GNI World Bank \\
\hline Hurricane loss st. dev & $\sigma_{h}$ & 0.029 & 0.028 & 0.028 & 0.034 & 0.052 & 0.027 & 0.02 & GDP/GNI World Bank \\
\hline Discount Factor & $\beta$ & 0.90 & 0.9425 & 0.905 & 0.88 & 0.90 & 0.805 & 0.88 & Debt/GDP \\
\hline Output cost & $\delta$ & 0.80 & 0.6 & 0.79 & 0.84 & 0.77 & 0.85 & 0.82 & Mean spread \\
\hline
\end{tabular}

Panel A reports parameter values for standard parameters that are calibrated to the same value in every country and the associated target statistics. Panel B reports country-specific parameter values that are used for the calibration of the model and the associated target statistics. Parameters above the line are calibrated independently. Parameters below the line are jointly calibrated to match the average spread level and the average debt-to-GDP ratio 


\section{Quantitative Analysis}

In this section I first compare moments in the model economy with those in the data. Next, I evaluate the impact of hurricane risk and climate change on government policies, showing that disaster risk and climate change reduce governments' ability to issue debt.

\subsection{Moment Matching Exercise}

Table 2 reports key moments in the data (Panel A) for the seven Caribbean countries in the sample. There is considerable variety across countries in terms of average debt-to-GDP ratios and spreads. Debt-to-GDP ratios oscillate from 0.27 in Dominican Republic to 0.78 in Belize. Average spreads range from 109bp in Belize to 519 in Jamaica. The sample also display significant heterogeneity in terms of the frequency and the economic impact of hurricanes. The annual probability of major hurricane hits ranges from almost $14 \%$ in Antigua (one hit every 7 years) to $2.6 \%$ in Dominican Republic (one hit every 38 years). The average GDP contraction after hurricane hits ranges from $9.8 \%$ in Dominica to $2.3 \%$ in Jamaica.

Panel B reports moments obtained from the model. The comparison between Panel A and Panel B shows that the model replicates almost perfectly the debt-to-GDP ratio and the average spread in every country, which were jointly targeted by the calibration exercise. At the same time, the model also matches well the incidence of hurricanes and their average impact on the GDP, confirming that parameter choices for the incidence of hurricanes and their intensity are correct.

Panel B also reports default frequencies, which were not directly targeted in Section 4 . The model replicates them fairly well. Belize is the country with the lowest default frequency both in the data and in the model. At the same time, the model predicts a default incidence or about $4.5 \%$ in Antigua y Barbuda, Dominican Republic, Granada, and Jamaica. This result is in line with the empirics where the default incidence in these countries is close to $5 \%$.

\subsection{Sovereign Risk and Hurricanes}

How much does hurricane risk affect government policies? To answer this question I solve a version of the model that eliminates hurricane risk, setting the probability $p_{h}$ of the hurricane shock equal to zero. Figure 1 compares the price function of government debt in the baseline economy and in the economy without hurricane risk. ${ }^{17}$ Absent hurricane risk, the price function shifts to the right implying that borrowing terms improve.

\footnotetext{
${ }^{17}$ Figure 1 reports price schedules for Antigua y Barbuda. Price schedules of other countries are similar.
} 
Table 2. Quantitative Analysis

Panel A: Moments from the Data

\begin{tabular}{lccccccc}
\hline \hline Moment & Antigua & Belize & Dominica & Dominican Rep. & Grenada & Honduras & Jamaica \\
\hline \hline Average Spread & 448 & 109 & 366 & 483 & 493 & 411 & 519 \\
Ext. Debt/GDP ratio & 0.36 & 0.78 & 0.56 & 0.25 & 0.53 & 0.35 & 0.49 \\
Hurricane Frequency & 0.103 & 0.077 & 0.026 & 0.051 & 0.051 & 0.051 & 0.103 \\
GDP Loss- Hurricane & 0.049 & 0.021 & 0.098 & 0.040 & 0.070 & 0.052 & 0.023 \\
Default Frequency & 0.051 & - & 0.026 & 0.051 & 0.051 & 0.026 & 0.051 \\
\hline \hline
\end{tabular}

Panel B: Simulated Moments

\begin{tabular}{lccccccc}
\hline \hline Moment & Antigua & Belize & Dominica & Dominican Rep. & Grenada & Honduras & Jamaica \\
\hline \hline Average Spread & 466 & 143 & 378 & 497 & 499 & 423 & 526 \\
Ext. Debt/GDP ratio & 0.39 & 0.72 & 0.56 & 0.25 & 0.54 & 0.34 & 0.53 \\
Hurricane Frequency & 0.098 & 0.061 & 0.026 & 0.046 & 0.049 & 0.049 & 0.091 \\
GDP Loss - Hurricane & 0.046 & 0.028 & 0.094 & 0.042 & 0.071 & 0.049 & 0.025 \\
Default Frequency & 0.044 & 0.014 & 0.033 & 0.040 & 0.047 & 0.028 & 0.043 \\
\hline \hline
\end{tabular}

Panel C: Simulated Moments - No Hurricanes

\begin{tabular}{lccccccc}
\hline \hline Moment & Antigua & Belize & Dominica & Dominican Rep. & Grenada & Honduras & Jamaica \\
\hline \hline Average Spread & 341 & 88 & 270 & 423 & 377 & 283 & 400 \\
Ext. Debt/GDP ratio & 0.51 & 1.04 & 0.63 & 0.28 & 0.60 & 0.38 & 0.67 \\
Default Frequency & 0.030 & 0.006 & 0.020 & 0.034 & 0.035 & 0.016 & 0.030 \\
\hline \hline
\end{tabular}

Panel A reports key moments from the data for each of the seven Caribbean countries. Panel B reports moment obtained simulating the model economy for 9,500 periods. Panel C reports moment obtained eliminating hurricane risk. GDP Loss - Hurricane captures the average GDP contraction observed in the year of a major hurricane direct hit.

To quantify the impact of disaster risk on the government policy, I simulate the model economy without hurricane risk and compare simulated moments with those obtained in the baseline economy. Results are reported in Panel $\mathrm{C}$ of Table 2. Two results emerge. First, average spreads are lower than in the baseline economy, confirming that borrowing terms improve when disaster risk is eliminated. Second, governments issue more debt and debt-to-GDP ratios increase. According to model simulations, spreads would be on average $27 \%$ lower and the debt-to-GDP ratio would be on average $21 \%$ higher, absent hurricane risk. The increase of the debt ratios and the decline of sovereign spreads is more marked in countries that are most frequently hit by hurricanes: Antigua, Belize, and Jamaica. 
Figure 1. Price of Government Debt without Hurricane Risk

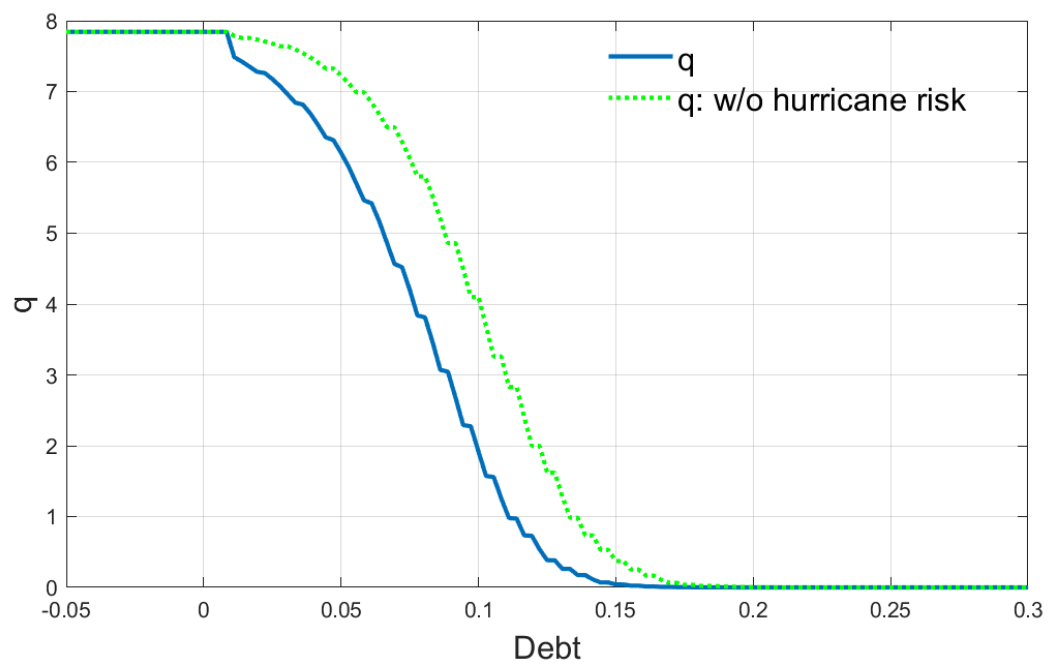

The blue line plots the price schedule for Antigua y Barbuda's government bonds in the benchmark model. The green dashed line plots the price schedule for Antigua y Barbuda's government bonds in the model without hurricane risk.

\subsection{Climate Change}

Reliable records for major hurricanes only date back as far as complete global satellite observations. Nevertheless, scientists have found evidence that hurricanes have already become stronger and more destructive, amid rising global temperatures. In particular, while the overall frequency of hurricanes has remained stable since 1975, the incidence of category 3-5 hurricanes, which according to NOAA are responsible for $85 \%$ of all damages from hurricanes, has increased between 25\% and 30\% (Holland and Bruyere, 2013).

Going forward, scientists expect the frequency of high-category hurricanes to increase even further as hurricanes become stronger and more powerful. Bender et al. (2010), for instance, project that the frequency of category 4 and 5 hurricanes will increase more than $90 \%$ by the end of the twenty-first century. In a related paper, Bhatia et al. (2018) estimate that the frequency of major cyclones will increase roughly $30 \%$ in the Atlantic by 2081-2100, with the frequency of category 5 storms jumping $136 \%$.

Not only will high-category hurricanes become more frequent, they will also become more intense. A number of studies project rainfall to increase (Emanuel, 2017), winds to pick up (Bhatia et al., 2018), and hurricanes' forward speed to decline (Kossin, 2018) by the end of the twenty-first century. Bhatia et al. (2018), in particular, find that tropical cyclones will more routinely reach wind speeds that are well above the category 5 threshold, hinting that the SaffirSimpson scale might need to be extended to include higher categories. With tropical cyclones becoming more intense, rising sea level, and increasing population in the 
coastal areas, the economic damages caused by hurricanes are poised to increase sharply. Nordhaus (2010) studies the economic cost of hurricanes in the Atlantic coastal United States and finds that a $2.5^{\circ} \mathrm{C}$ increase of global temperatures, will cause a $113 \%$ increase of the economic costs associated with hurricanes. Similarly, Mejia (2016) estimates that the economic cost of hurricanes will increase between $20 \%$ and $77 \%$ due to the increase of wind speed.

Table 3. Climate Change

Panel A: 1.292x Hurricanes' Frequency - 1.485x Hurricanes' Damages

\begin{tabular}{lccccccc}
\hline \hline Moment & Antigua & Belize & Dominica & Dominican Rep. & Grenada & Honduras & Jamaica \\
\hline \hline Average Spread & 655 & 185 & 494 & 591 & 613 & 618 & 658 \\
Ext. Debt/GDP ratio & 0.33 & 0.51 & 0.54 & 0.24 & 0.50 & 0.32 & 0.43 \\
Hurricane Frequency & 0.133 & 0.089 & 0.035 & 0.063 & 0.066 & 0.066 & 0.124 \\
GDP Loss - Hurricane & 0.062 & 0.033 & 0.139 & 0.056 & 0.096 & 0.071 & 0.031 \\
Default Incidence & 0.057 & 0.017 & 0.044 & 0.047 & 0.056 & 0.045 & 0.057 \\
\hline \hline
\end{tabular}

Panel B: 1.292x Hurricanes' Frequency

\begin{tabular}{lccccccc}
\hline \hline Moment & Antigua & Belize & Dominica & Dominican Rep. & Grenada & Honduras & Jamaica \\
\hline \hline Average Spread & 516 & 161 & 409 & 522 & 534 & 466 & 565 \\
Ext. Debt/GDP ratio & 0.37 & 0.64 & 0.54 & 0.25 & 0.52 & 0.33 & 0.48 \\
Hurricane Frequency & 0.128 & 0.079 & 0.034 & 0.059 & 0.062 & 0.061 & 0.12 \\
GDP Loss - Hurricane & 0.044 & 0.028 & 0.094 & 0.043 & 0.070 & 0.049 & 0.023 \\
Default Incidence & 0.047 & 0.018 & 0.036 & 0.041 & 0.049 & 0.032 & 0.049 \\
\hline \hline
\end{tabular}

Panel C: 1.485x Hurricanes' Damages

\begin{tabular}{lccccccc}
\hline \hline Moment & Antigua & Belize & Dominica & Dominican Rep. & Grenada & Honduras & Jamaica \\
\hline \hline Average Spread & 549 & 163 & 457 & 531 & 564 & 559 & 581 \\
Ext. Debt/GDP ratio & 0.35 & 0.61 & 0.55 & 0.24 & 0.52 & 0.34 & 0.47 \\
Hurricane Frequency & 0.101 & 0.068 & 0.027 & 0.050 & 0.052 & 0.052 & 0.102 \\
GDP Loss - Hurricane & 0.065 & 0.032 & 0.140 & 0.058 & 0.093 & 0.072 & 0.032 \\
Default Incidence & 0.049 & 0.015 & 0.039 & 0.044 & 0.052 & 0.042 & 0.052 \\
\hline \hline
\end{tabular}

Panel A reports moments obtained simulating the model economy for 9,500 periods assuming that the frequency of hurricanes increases $29.2 \%$ and the intensity of the damages increase $48.5 \%$. Panel B reports moments obtained simulating the economy and assuming that the frequency of hurricanes increases $29.2 \%$, while their intensity stays constant. Panel C reports moments obtained simulating the economy and assuming that the intensity increases $48.5 \%$, while their frequency stays constant. GDP Loss - Hurricane captures the average GDP contraction observed in the year of a major hurricane direct hit. 
In this paper I examine the scenario in which the frequency of high category hurricanes increases $29.2 \%$ as projected by Bhatia et al. (2018) and hurricane damages increase 48.5\%, which is the mean value of the estimates in Mejia (2016). Panel A of Table 3 reports simulated moment for the seven Caribbean economies in the climate change scenario. Relative to the baseline economy the frequency of defaults increases on average $30 \%$ in the seven countries in the sample. At the same time, spreads also increase on average $31 \%$ on the account of climate change. As borrowing costs increase, debt levels decline with the debt-to-GDP ratio falling on average $12 \%$ relative to the baseline scenario. A closer inspection of the results shows some heterogeneity across countries. In Antigua, where hurricanes are already frequent and intense, the debt-to-GDP ratio declines $16 \%$ and spreads increase $40 \%$. On the opposite side of spectrum, the debt-to-GDP ratio only declines $7 \%$ and spreads increase $18 \%$ in the Dominican Republic.

Panel B and C of Table 3 unpack the impact of climate change on the economy and isolate the consequences for the economy of the higher frequency of hurricanes from the consequences of the increasing intensity of hurricanes. Panel B looks at the case in which the frequency of high-category hurricanes increases, but their intensity is unchanged. Panel $\mathrm{C}$ looks at the opposite case in which the frequency of high-category hurricanes stays the same, while their intensity increases. Broadly speaking, frequency and intensity have the same impact on government borrowing policies. In both cases, debt-to-GDP ratios decline and, at the same time, spreads increase. ${ }^{18}$ Yet, the projected increase in the intensity of hurricanes has a bigger impact on government policies than the projected increase in the frequency of hurricanes, suggesting that major hurricanes already have the potential of pushing countries to default. Hence, their frequency more than their intensity matters to shape governments' policy functions. Debt-to-GDP ratios only decline $9 \%$ as the frequency of hurricanes increases, while they decline $17 \%$ when the intensity of hurricanes increases.

\section{Hurricane Clause}

In 2013 Grenada introduced a "hurricane clause", that allows for an immediate, albeit temporary, debt moratorium when the country is hit by hurricanes causing damages in excess of $\$ 15$ million. Grenada's decision to introduce a hurricane clause was endorsed by the Paris Club and, more broadly, , disaster clauses have received incrseaing attention in policy circles, as they are perceived as effective tools to adapt to climate change. ${ }^{19}$ In this section, I modify the baseline model to analyze the impact of disaster clauses on governments' policies.

\footnotetext{
${ }^{18}$ Results in section 6 , show that with hurricane clauses debt-to-GDP ratios do not decline, but rather inch up in several countries.

${ }^{19}$ Bonds that include disaster clauses are often refered to as CAT bonds.
} 


\subsection{Modeling the Hurricane Clause}

Hurricane clauses allow governments to suspend debt servicing when major hurricanes hit. Hence, when countries are hit by major hurricanes, governments face three options: default, repay, or activate the hurricane clause and receive debt-servicing relief. Government's optimal default and debt-servicing relief decisions solve:

$$
V=\max _{d, r e l}\left\{\xi\left((1-d-r e l) V^{n d}+r e l V^{r e l}+d V^{d}\right)+(1-\xi)\left((1-d) V^{n d}+d V^{d}\right)\right\} .
$$

Where $\xi$ is an indicator that is equal to one when the economy is hit by a major hurricane and $r e l$ is a dummy variable that takes the value of one when the government activates the disaster clause. $V^{r e l}$ is the value function when the government requests the debt-servicing relief. $V^{n d}$ and $V^{d}$ are investors' value function in the non-default scenario and in the default scenario respectively, which were already defined in Section 3. ${ }^{20}$ Following the example of Grenada, it is assumed that the debt-servicing suspension lasts only one year. The value function $V^{\text {rel }}$ can be defined as follows:

$$
\begin{gathered}
V^{r e l}(y, h, b,)=u(c)+\beta \mathbb{E}\left[V\left(y^{\prime}, h^{\prime}, b\right)\right] \\
\text { s.t. } c=y .
\end{gathered}
$$

Equation (12) is the resource constraint of the economy prescribing that consumption equals income. When the government requests debt-servicing relief, it stops servicing debt and borrowing from abroad for one period. As indicated by the continuation value in (12), in $t+1$ debt repayments suspensions ends. Hence, any government that activates the disaster clause in time $t$, resumes servicing the debt in $t+1$. Crucially, there are no endowment costs associated with the activation of the hurricane clause.

International investors price government bonds by arbitrage taking into consideration the existence of the hurricane clause. The asset pricing equation for government bonds becomes:

$$
\begin{gathered}
q\left(y^{\prime}, h^{\prime}, b^{\prime}\right)=\frac{1}{\left(1+r^{f}\right)} E\left[\left(1-d^{\prime}-r e l^{\prime}\right)+(1-\psi)\left(1-d^{\prime}-r e l^{\prime}\right) q^{\prime}\right. \\
\left.+\frac{r e l^{\prime}}{\left(1+r^{f}\right)} E\left[\left(1-d^{\prime \prime}-r e l^{\prime \prime}\right)+(1-\psi)\left(1-d^{\prime \prime}-r e l^{\prime \prime}\right) q^{\prime \prime} \mid y^{\prime}\right] \mid y\right]
\end{gathered}
$$

As it is standard in the literature, the price of government bonds depends on the risk-free rate and the default risks. Additionally, with the introduction of hurricane clauses, the price also depends on the risk that the government activates such clause, and a term that accounts for the expected discounted value of maturing bonds after the government resumes payments. ${ }^{21}$

\footnotetext{
${ }^{20}$ The maximization problems that define $V^{n d}$ and $V^{d}$ in the economy with disaster clauses are similar to those presented in Section 3, with the exception that the price of government bond is different and the value function $V\left(y^{\prime}, h^{\prime}, b\right)$ also include the debt-servicing relief option.

${ }^{21}$ Section 8.4 in the Appendix formally derives equation (13).
} 


\subsection{Quantitative Analysis}

Figure 2 compares the price schedule of government bonds in the benchmark model and in the model with the hurricane clause. ${ }^{22}$ The price of government debt is generally higher with the hurricane clause. The hurricane clause allows governments to postpone payments when disasters hit and thereby avoid defaults. Hence borrowing terms improve. For very low levels of debt, however, the price of government debt is higher in the baseline model. This finding is explained by the fact that governments may still activate the hurricane clause, even when debt levels are very low. Hence, investors need to receive a compensation for the risk of a delay in the repayment schedule. In the baseline model, instead, such risk does not exist and, for very low levels of debt, default risk is also zero.

Figure 2. Price of Government Debt

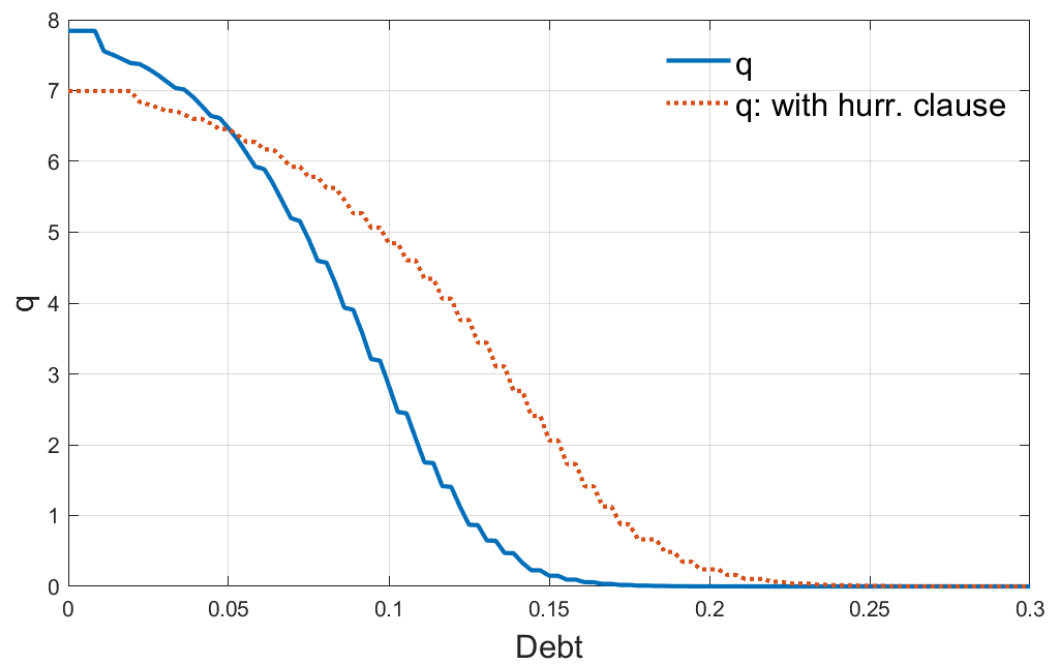

The blue line plots the price schedule for Antigua y Barbuda's government bonds in the benchmark model. The red dashed line plots the price schedule or Antigua y Barbuda's government bonds in the model with the disaster clause.

Table 4 reports simulated long-run moments for the model economy with the disaster clause. A comparison with Panel B of Table 2 shows that the disaster clause allows governments to borrow more and sustain higher debt-to-GDP levels. Relative to the baseline model, the debt-to-GDP ratio is on average $32 \%$ higher. The increase of debt-to-GDP ratios is especially

\footnotetext{
${ }^{22}$ The graph reports the price function for the government debt of Antigua y Barbuda. Price functions of other countries look similar.
} 
pronounced in Antigua, Belize, and Jamaica, which are the countries that would active the hurricane clause more frequently.

Results in Table 4 also show that, in equilibrium, borrowing costs increase noticeably, despite the decline of the borrowing terms reported in the Figure 2. Spreads surge $30 \%$ across the board and more than double in Belize. Yet, the frequency of defaults is almost unchanged. Together these two results explain how governments modify their borrowing behavior in response to the hurricane clause. Governments take advantage of the lower borrowing terms and expand their borrowings so much that the default risk is almost unchanged relative to the baseline economy without hurricane clauses. Spreads, however, are higher, as governments need to compensate investors for the additional risk that debt repayments are postponed..$^{23}$ Of note, governments are willing to pay higher spreads, as disaster clauses reduce the effective costs of repaying the debt, allowing governments to push forward debt repayments.

Table 4. Hurricane Clause

\begin{tabular}{lccccccc}
\hline \hline Moment & Antigua & Belize & Dominica & Dominican Rep. & Grenada & Honduras & Jamaica \\
\hline \hline Average Spread & 628 & 311 & 394 & 647 & 620 & 317 & 700 \\
Ext. Debt/GDP ratio & 0.57 & 1.33 & 0.60 & 0.29 & 0.65 & 0.39 & 0.76 \\
Hurricane Frequency & 0.134 & 0.060 & 0.026 & 0.046 & 0.048 & 0.049 & 0.09 \\
GDP Loss - Hurricane & 0.042 & 0.028 & 0.095 & 0.044 & 0.074 & 0.051 & 0.024 \\
Default Incidence & 0.047 & 0.030 & 0.034 & 0.054 & 0.054 & 0.012 & 0.040 \\
\hline \hline
\end{tabular}

This table reports moments obtained calibrating the model economy with the hurricane clause to each of the seven Caribbean economies in the sample, and simulating each economy for 9,500 periods. GDP Loss - Hurricane captures the average GDP contraction observed in the year of a major hurricane direct hit.

\subsection{Climate Change}

In this section, I check how climate change impacts government policies when government bonds feature the hurricane clause. Panel A in Table 5 reports key moments for the model economy with hurricane clauses in the climate change scenario, that assumes a $29.2 \%$ increase in the frequency of major hurricanes and a $48.5 \%$ increase in their intensity. Comparing results in Panel A with those in Table 4, I find that, relative to the scenario without climate change, debt levels are little changed. This result is in sharp contrast with the one presented in Section 5.3 showing that climate change reduces government ability to issue debt, when

\footnotetext{
${ }^{23}$ Figure 3 in the Appendix further clarifies the point showing that in equilibrium governments expand their borrowings so much the the equilibrium price of government debt is higher in the model with the hurricane clause.
} 
Table 5. Climate Change

Panel A: 1.292x Hurricanes' Frequency - 1.485x Hurricanes' Damages

\begin{tabular}{lccccccc}
\hline \hline Moment & Antigua & Belize & Dominica & Dominican Rep. & Grenada & Honduras & Jamaica \\
\hline \hline Average Spread & 962 & 506 & 436 & 697 & 720 & 332 & 883 \\
Ext. Debt/GDP ratio & 0.61 & 1.24 & 0.60 & 0.31 & 0.68 & 0.39 & 0.69 \\
Hurricane Frequency & 0.133 & 0.089 & 0.034 & 0.063 & 0.065 & 0.067 & 0.128 \\
GDP Loss- Hurricane & 0.062 & 0.034 & 0.141 & 0.057 & 0.098 & 0.072 & 0.031 \\
Default Incidence & 0.039 & 0.025 & 0.018 & 0.036 & 0.045 & 0.003 & 0.036 \\
\hline \hline
\end{tabular}

Panel B: 1.292x Hurricanes' Frequency

\begin{tabular}{lccccccc}
\hline \hline Moment & Antigua & Belize & Dominica & Dominican Rep. & Grenada & Honduras & Jamaica \\
\hline \hline Average Spread & 871 & 451 & 416 & 661 & 686 & 366 & 835 \\
Ext. Debt/GDP ratio & 0.67 & 1.41 & 0.63 & 0.33 & 0.73 & 0.41 & 0.78 \\
Hurricane Frequency & 0.1128 & 0.078 & 0.033 & 0.059 & 0.060 & 0.065 & 0.117 \\
GDP Loss-Hurricane & 0.044 & 0.029 & 0.095 & 0.044 & 0.072 & 0.049 & 0.024 \\
Default Incidence & 0.034 & 0.022 & 0.020 & 0.035 & 0.043 & 0.006 & 0.035 \\
\hline \hline
\end{tabular}

Panel C: 1.485x Hurricanes' Damages

\begin{tabular}{lccccccc}
\hline \hline Moment & Antigua & Belize & Dominica & Dominican Rep. & Grenada & Honduras & Jamaica \\
\hline \hline Average Spread & 804 & 400 & 411 & 632 & 645 & 332 & 753 \\
Ext. Debt/GDP ratio & 0.60 & 1.26 & 0.60 & 0.31 & 0.66 & 0.38 & 0.68 \\
Hurricane Frequency & 0.101 & 0.068 & 0.026 & 0.050 & 0.051 & 0.050 & 0.099 \\
GDP Loss- Hurricane & 0.065 & 0.035 & 0.141 & 0.056 & 0.100 & 0.074 & 0.032 \\
Default Incidence & 0.038 & 0.023 & 0.021 & 0.036 & 0.043 & 0.005 & 0.036 \\
\hline \hline
\end{tabular}

Panel A reports moments obtained simulating the model economy with the hurricane clause for 9,500 periods assuming that the frequency of hurricanes increases $29.2 \%$ and the intensity of the damages increases $48.5 \%$. Panel B reports moments obtained simulating the economy with the hurricane clause and assuming that the frequency of hurricanes increases $48.5 \%$, while their intensity stays constant. Panel $\mathrm{C}$ reports moments obtained simulating the economy with the hurricane clause and assuming that the intensity of hurricanes increases $48.5 \%$, while their frequency stays constant. GDP Loss - Hurricane captures the average GDP contraction observed in the year of a major hurricane direct hit.

government bonds do not feature the disaster clause. Unlike debt levels, borrowing terms are heavily affected by climate change. Spreads increase on average $27 \%$ in our sample and increase more than $60 \%$ in Belize. The steep rise of sovereign yields is explained by two factors. First and foremost, governments need to compensate investor for the risk that the hurricane clause is activated more frequently. Second, default risk also increases slightly as 
shown by the marginal increase in the frequency of defaults.

Panel B isolates the impact of hurricanes' frequency on governments' policies. Comparing results in Panel B with those in Table 4, I find that an increase in the frequency of defaults is accompanied by higher debt-to-GDP ratios and higher spreads, which increase on average $9 \%$ and $20 \%$ respectively. Spreads increase as investors need to be compensated for the fact that the hurricane clause is activated more frequently. ${ }^{24}$ Debt levels increase due to moral hazard. When the frequency of hurricanes increases, governments can activate the hurricane clause more frequently, delaying debt repayment and thereby reducing the expected discounted cost of servicing the debt. In other words, governments engage in "gambling for debt-servicing suspension" behavior. They borrow more and at a higher cost, as the hurricane clauses reduces the effective cost of repaying the debt.

Panel C isolates the impact of hurricanes' intensity on governments' policies. The comparison between Panel $\mathrm{C}$ and Table 4 shows that an increase of the intensity of hurricanes is accompanied by higher spreads in all countries and declines of debt levels in most countries. These results echo those presented in Section 5.3 and suggest that hurricane clauses do not preserve governments' access to financial market when the intensity of financial markets increases.

All told, results suggest that disaster clauses can be an effective tool to preserve governments' market access amid rising risk of natural disasters. However, market access comes with a cost. Disaster clauses incentivize governments to "gamble for debt-servicing suspension", issuing more debt and paying higher yields.

\subsection{Welfare Analysis and Debt Limits}

To quantify the welfare gains associated with disaster clauses, I compute consumption equivalents, that correspond to the percentage increases in consumption that an agent in the baseline economy should be given in any period and in any state of the world to achieve the same utility as in the economy with disaster clauses. Formally, let $c^{*}$ be the equilibrium consumption in the baseline economy and let $c_{W C}^{*}$ be the equilibrium consumption in the economy with disaster clauses. The consumption equivalent welfare change $\Delta_{W C}$ that makes agents indifferent between the baseline economy and the one with disaster clauses is:

$$
V\left(c^{*}\left(1+\Delta_{W C}\right)\right)=V\left(c_{W C}^{*}\right) .
$$

Similarly the consumption equivalent welfare change $\Delta_{W C, C C}$ that makes agents indifferent between having or not having disaster clauses in the climate change scenario is:

$$
V\left(c_{C C}^{*}\left(1+\Delta_{W C, C C}\right)\right)=V\left(c_{W C, C C}^{*}\right) .
$$

\footnotetext{
${ }^{24}$ The frequency of default reported in Panel B is lower than in the scenario without climate change in Table 4 . Hence, the rise in the spreads is fully explained by the increasing risk of delayed payments.
} 
Where $c_{C C}^{*}$ is the equilibrium consumption in the baseline economy with climate change, while $c_{W C, C C}^{*}$ is the equilibrium consumption in the economy with disaster clauses and climate change.

Table 6. Welfare Analysis

Panel A: Welfare Analysis - Disaster Clause

\begin{tabular}{lccccccc}
\hline \hline Moment & Antigua & Belize & Dominica & Dominican Rep. & Grenada & Honduras & Jamaica \\
\hline \hline$\Delta_{W C}$ & $-2.76 \%$ & $-7.09 \%$ & $-0.96 \%$ & $-1.22 \%$ & $-1.60 \%$ & $-1.57 \%$ & $-1.41 \%$ \\
$\Delta_{W C, C C}$ & $-2.87 \%$ & $-11.56 \%$ & $-0.82 \%$ & $-1.21 \%$ & $-1.75 \%$ & $-2.10 \%$ & $-2.18 \%$ \\
\hline \hline
\end{tabular}

Panel B: Welfare Analysis - Disaster Clause and Debt Limit

\begin{tabular}{lccccccc}
\hline \hline Moment & Antigua & Belize & Dominica & Dominican Rep. & Grenada & Honduras & Jamaica \\
\hline \hline$\Delta_{W L}^{D L}$ & $2.02 \%$ & $3.63 \%$ & $0.26 \%$ & $1.34 \%$ & $1.06 \%$ & $1.19 \%$ & $1.87 \%$ \\
$\Delta_{W L}^{D L}$ & $2.10 \%$ & $3.10 \%$ & $0.06 \%$ & $1.28 \%$ & $0.93 \%$ & $0.50 \%$ & $1.84 \%$ \\
\hline \hline
\end{tabular}

Panel A reports consumption equivalents that make agents indifferent between the economy featuring disaster clauses and the economy without them. $\Delta_{W C}$ are consumption equivalents computed in the baseline scenario. $\Delta_{W C, C C}$ are consumption equivalents computed in the economy with climate change. Panel $\mathrm{B}$ reports consumption equivalents that make agents indifferent between the economy with disaster clauses and debt limits and the economy without them. $\Delta_{W C}^{D L}$ are consumption equivalents computed in the baseline scenario. $\Delta_{W C, C C}^{D L}$ are consumption equivalents computed in the economy with climate change.

Panel $\mathrm{A}$ in Table 6 reports estimated values for $\Delta_{W C}$ and $\Delta_{W C, C C}$ for each of the seven countries in our sample. Consumption equivalents are negative, meaning that disaster clauses reduce welfare. This is true both in the baseline scenario and in the scenario with climate change. In quantitative models of sovereign defaults government debt is ex-ante optimal, but ex-post suboptimal. At time $t$, the governments want to borrow from abroad to boost consumption. However, in the following periods government regret past borrowings, as part of the income is transferred abroad to repay the debt, leading to a decline in consumption. As reported in Table 4 and in Table 5, debt levels increase noticeably in all countries with the introduction of hurricane clauses. It is therefore not surprising that welfare declines everywhere.

The welfare analysis highlights the tension between the size of government debt and welfare. On the one side, governments want to borrow cheaply and reduce the cost of servicing debt. On the other side, when borrowing costs decline, governments issue more debt causing consumption and welfare to decline. The existence of such trade-off suggests that a combination of policies that reduce borrowing costs and keep debt levels under control may improve welfare over the cycle. To verify this intuition, I examine the welfare implications of a policy 
that introduces disaster clauses and at the same time caps government debt to the levels observed in the economy without disaster clauses. ${ }^{25}$.

Table 8 in the Appendix 8.5 reports simulated moments for the model economies with both debt limits and disaster clauses. Debt-to-GDP ratios are almost identical to the ones observed in the economy without the disaster clause. Spreads, however, are lower. Panel B in Table 6 reports consumption equivalent welfare gains associated with such combination of policies. $\Delta_{W C}^{D L}$ is the consumption equivalent measuring welfare gains of the simultaneous introduction of disaster clauses and debt limits in the baseline scenario. ${ }^{26} \Delta_{W C, C C}^{D L}$ is the consumption equivalent in the corresponding climate change scenario. ${ }^{27} \mathrm{I}$ find that welfare increases in all countries, confirming the intuition that debt limits must be introduced together with disaster clauses to avoid a decline in welfare. Gains are larger in countries that are more frequently hit by hurricanes and range from $0.26 \%$ percent in Dominica to $3.63 \%$ percent in Belize. Of note, welfare gains are positive both in the baseline scenario and in the climate change scenario.

\section{Concluding Remarks}

This paper investigates the impact of extreme weather on government's borrowing and default policies through the lens of a quantitative sovereign default model. In particular, I focus on a sample of small Caribbean countries that are exposed to hurricane risk. I find that extreme weather restricts government ability to issue debt. Such finding is worrying in light of the fact that extreme weather events and natural disasters are poised to become even more sizable in the coming years, amid rapid climate change. In this paper, I show that in a scenario in which the frequency of high-category hurricanes increase $29.2 \%$ and their intensity increases $48.5 \%$, as predicted by the climate-change literature, debt-to-GDP ratios will decline more than $12 \%$ and spreads will increase more than $30 \%$.

Next, I explore whether disaster clauses, that allow governments to suspend payments in the event of natural disasters, can facilitate government access to international financial markets. I find that disaster clauses reduce borrowing terms, allowing government to issue

${ }^{25}$ The maximization problem of the government is formally defined in Appendix 8.5

${ }^{26}$ Formally, the consumption equivalent $\Delta_{W C}^{D L}$ solves:

$$
V\left(c^{*}\left(1+\Delta_{W C}^{D L}\right)\right)=V\left(c_{W C}^{*, D L}\right) .
$$

Where $c_{W C}^{*, D L}$ is the equilibrium consumption in the economy with both debt limits and disaster clauses.

${ }^{27}$ Formally, the consumption equivalent $\Delta_{W C, C C}^{D L}$ solves:

$$
V\left(c^{*}\left(1+\Delta_{W C, C C}^{D L}\right)\right)=V\left(c_{W C, C C}^{*, D L}\right) .
$$

Where $c_{W C, C C}^{*, D L}$ is the equilibrium consumption in the economy with both debt limits and disaster clauses in the climate change scenario. 
more debt. However, I they also induce governments to engage in "gambling for debtservicing suspension" and borrow more. In equilibirum both spreads and debt levels increase sizably. Hurricane clauses also preserve governments' access to financial markets, amid an increase in the frequency of natural disaster.

Finally, I analyze welfare gains associated with disaster clauses. I find that disaster clauses may reduce welfare as the induce governments to issue more debt. a combination of disaster clauses and debt limits may successfully increase welfare.

Two of the modeling assumptions are worth discussing. Throughout the paper, it is assumed that the pool of investors that buy government bonds does not change after the introduction of the disaster clause. Yet, complex bonds that entail a disaster clause may only appeal to sophisticated traders. If this is the case, the potential pool of investors may become smaller reducing the appeal of disaster clauses and altering the price schedule of government bonds. The second assumption is about the design of disaster clauses. In the paper it is assumed that the activation of disaster clauses provides full debt-servicing relief. This assumption is consistent with the way disaster clauses are structured in the real world. Yet, results may change if the debt-servicing relief was only partial or proportional to the severity of hurricanes. In general, further research is needed to identify the optimal design of disaster clauses.

Concluding, this paper takes a first step in the direction of uncovering the unexplored relation between sovereign risk, natural disasters, and climate change. Several questions, however, remain open. In particular, additional effort should be devoted to understand the role of official lenders and insurance schemes, amid a disaster. At the same time, the optimal design of disaster clauses also deserves greater attention. These could certainly be interesting areas future research. 


\section{References}

Alessandria, George, Minjie Deng, and Yan Bai, "Sovereign Default Risk and Migration," Technical Report 2019.

Arellano, Cristina, "Default Risk and Income Fluctuations in Emerging Economies," American Economic Review, 2008, 98 (3), 690-712.

_, Yan Bai, and Gabriel Mihalache, "Deadly Debt Crises: COVID-19 in Emerging Markets," Staff Report 603, Federal Reserve Bank of Minneapolis May 2020.

Asonuma, Tamon, Xin Li, Michael G. Papaioannou, Saji Thomas, and Erika Togo, "Sovereign Debt Restructurings in Grenada; Causes, Processes, Outcomes, and Lessons Learned," Journal of Banking and Financial Economics, January 2018, 2 (10), $67-105$.

Balteanu, Irina and Aitor Erce, "Linking Bank Crises and Sovereign Defaults: Evidence from Emerging Markets," IMF Economic Review, December 2018, 66 (4), 617-664.

Barro, Robert J., "Rare Disasters, Asset Prices, and Welfare Costs," American Economic Review, March 2009, 99 (1), 243-264.

Belasen, Ariel R. and Solomon W. Polachek, "How Hurricanes Affect Wages and Employment in Local Labor Markets," American Economic Review, May 2008, 98 (2), $49-53$.

Bender, Morris A., Thomas R. Knutson, Robert E. Tuleya, Joseph J. Sirutis, Gabriel A. Vecchi, Stephen T. Garner, and Isaac M. Held, "Modeled Impact of Anthropogenic Warming on the Frequency of Intense Atlantic Hurricanes," Science, January 2010, 327 (5964), 454-458.

Bhatia, Kieran, Gabriel Vecchi, Hiroyuki Murakami, Seth Underwood, and James Kossin, "Projected Response of Tropical Cyclone Intensity and Intensification in a Global Climate Model," Jouranl of Climate, 2018, 31.

Deryugina, Tatyana, Laura Kawano, and Steven Levitt, "The Economic Impact of Hurricane Katrina on Its Victims: Evidence from Individual Tax Returns," American Economic Journal: Applied Economics, April 2018, 10 (2), 202-233.

Eaton, Jonathan and Mark Gersovitz, "Debt with Potential Repudiation: Theoretical and Empirical Analysis," Review of Economic Studies, April 1981, 48 (2), 289-309.

Emanuel, Kerry, "Assessing the present and future probability of Hurricane Harvey's rainfall," Proceeding of the National Academy of Sciences, 2017, 114.

Gallagher, Justin and Daniel Hartley, "Household Finance after a Natural Disaster: The Case of Hurricane Katrina," American Economic Journal: Economic Policy, August 2017, 9 (3), 199-228. 
Gourio, Francois, "Disaster Risk and Business Cycles," American Economic Review, October 2012, 102 (6), 2734-2766.

Hatchondo, Juan Carlos and Leonardo Martinez, "Long-duration bonds and sovereign defaults," Journal of International Economics, September 2009, 79 (1), 117-125.

_ and _, "The politics of sovereign defaults," Economic Quarterly, 2010, 96 (3Q), 291-317.

Holland, Greg and Cindy L. Bruyere, "Recent intense hurricane response to global climate change," Climate Dynamics, 2013, (42), 617 - 627.

International Monetary Fund, "Dominican Republic; Country Report," IMF Staff Country Reports 99/117, International Monetary Fund October 1999.

_ , "Republic of Moldova; Country Report," IMF Staff Country Reports 99/110, International Monetary Fund September 1999.

Kossin, James P., "A global slowdown of tropical-cyclone translation speed," Nature, 2018, 558 (4), 104-107.

Mejia, Sebastian Acevedo, "Gone with the Wind; Estimating Hurricane and Climate Change Costs in the Caribbean," IMF Working Papers 16/199, International Monetary Fund October 2016.

Nordhaus, William D., "The Economics Of Hurricanes And Implications Of Global Warming," Climate Change Economics (CCE), 2010, 1 (01), 1-20.

Phan, Toan and Felipe Schwartzman, "Disasters and Defaults," Technical Report 2020.

Rebelo, Sergio, Neng Wang, and Jinqiang Yang, "Rare Disasters, Financial Development, and Sovereign Debt," NBER Working Papers 25031, National Bureau of Economic Research, Inc September 2018.

Reinhart, Carmen M., Vincent Reinhart, and Christoph Trebesch, "Global Cycles: Capital Flows, Commodities, and Sovereign Defaults, 1815-2015," American Economic Review, May 2016, 106 (5), 574-580.

Richmond, Christine and Daniel Dias, "Duration of Capital Market Exclusion: An Empirical Investigation," SSRN Electronic Journal, 072009.

Schumacher, Julian, Christoph Trebesch, and Chuck Fang, "Restructuring sovereign bonds: holdouts, haircuts and the effectiveness of CACs," Working Paper Series 2366, European Central Bank January 2020.

Sturzenegger, Federico and Jeromin Zettelmeyer, Debt Defaults and Lessons from a Decade of Crises, Vol. 1 of MIT Press Books, The MIT Press, August 2007.

Tauchen, George and Robert Hussey, "Quadrature-Based Methods for Obtaining Approximate Solutions to Nonlinear Asset Pricing Models," Econometrica, March 1991, 59 (2), 371-96. 
Tran, Brigite Roth and Martin J. Wilson, "The local economic impact of natural disasters," Technical Report 2019.

Vos, Rob, Pitou Dijck, Geske Dijkstra, Dougal Martin, and Niek Jong, The Suriname economy: experiences of the 1990s and challenges ahead 112000. 


\section{Online Appendix}

\subsection{Equilibrium}

Equilibrium In equilibrium, the government sets the policy for default or repayment and for the issuance or purchase of bonds, in order to maximize the welfare of the representative household, subject to the resource constraint of the small open economy and to the constraint implied by foreign lenders' pricing of debt. The equilibrium is formally defined below.

Definition 1. A recursive equilibrium in the small open economy is characterized by

- a set of value functions for the representative household $V, V^{n d}$, and $V^{d}$,

- government policies for default $d$ and asset holdings $b^{\prime}$,

- a government debt price function $q$

such that:

- the debt price function is consistent with optimization by foreign lenders, (8),

- given the debt price function $q$, the value functions of the household and the policy functions of the government solve the maximization problem (1), (2)-(24), (6)-(7).

- the resource constraint of the small open economy is satisfied 


\subsection{Chronology of Major Hurricanes}

Table 7. Major Hurricanes Hits

\begin{tabular}{|c|c|c|c|}
\hline & Dates & $\begin{array}{l}\text { Frequency } \\
1971-2019\end{array}$ & $\begin{array}{l}\text { Frequency } \\
1980-2019\end{array}$ \\
\hline Antigua & $\begin{array}{c}1871,1899,1928,1932, \\
1950,1960,1966,1989, \\
1995,1998,2017\end{array}$ & 0.074 & 0.138 \\
\hline Belize & $\begin{array}{l}1931,1955,1961,1974 \\
1978,2000,2001,2010\end{array}$ & 0.054 & 0.077 \\
\hline Dominica & $\begin{array}{c}1883,1891,1894,1899 \\
1928,1964,1966,1979 \\
2017\end{array}$ & 0.061 & 0.026 \\
\hline Grenada & $1955,1963,2004,2005$ & 0.027 & 0.051 \\
\hline Honduras & 1978,1998 & 0.014 & 0.051 \\
\hline Jamaica & $\begin{array}{c}1903,1912,1944,1951 \\
1980,1988,2004,2007\end{array}$ & 0.054 & 0.10 \\
\hline
\end{tabular}

Major hurricanes are those category 3 or higher. The first column reports the dates of direct hits. The second column reports the frequency of direct hits from 1871. The third column report the frequency of direct hits since 1980, which are also used in the calibration exercise. 


\subsection{Additional Graphs}

Figure 3. Policy Functions in the Model with Hurricane Clause
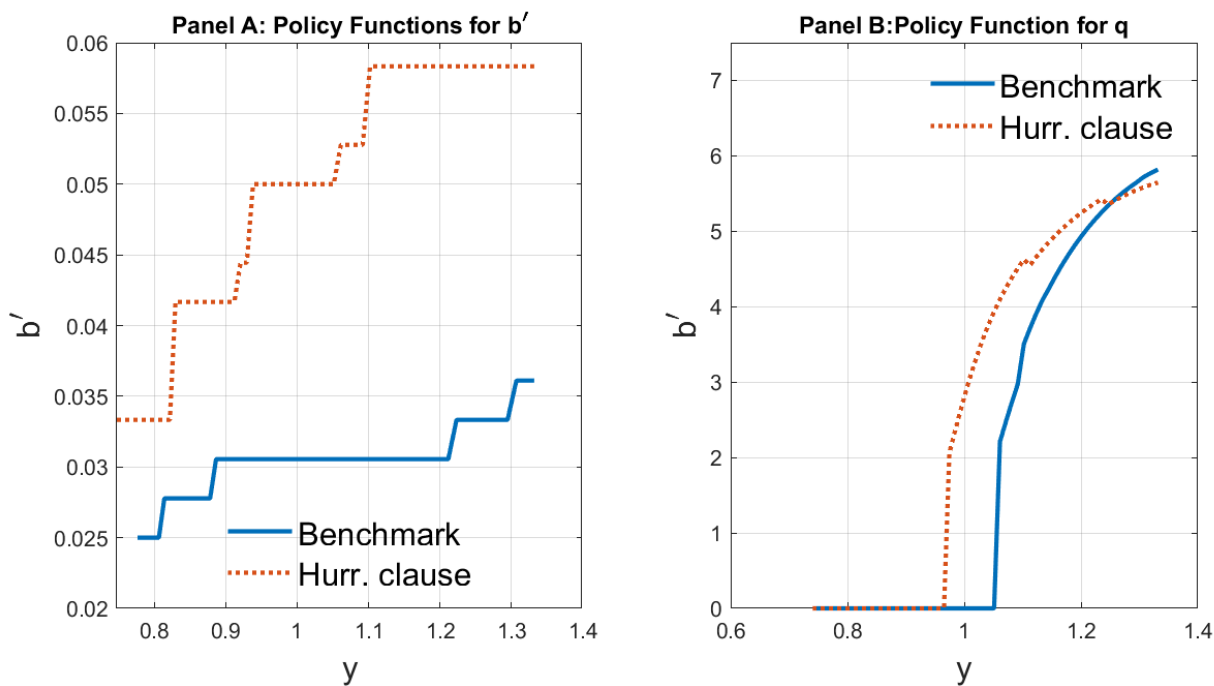

Panel A compares the policy functions for government debt in an economy without disaster clause (blue line) and in an economy with the disaster clause (orange dashed lined). Panel B compares the policy function for the price of government debt in an economy without disaster clause (blue line) and in an economy with the disaster clause (orange dashed lined)

\subsection{Investors' Maximization Problem with the Disaster Clause}

Investors are risk neutral, have deep pockets, and hold two types of assets: risk-free bonds $b_{r f}$ that pay $r^{r f}$ in every period, or risky government bonds $b_{L}$. Investors are price takers. Hence, they take the state variables that define the price of government debt as as given $s=\{y, h, b\}$ as well as governments' policies.

When the government is in autarky, investors' value function is:

$$
\begin{gathered}
V_{L}^{\text {def }}\left(s, b_{r f,}, 0\right)=\max _{c_{L}^{d e f}, b_{r f}^{\prime}} c_{L}^{\text {def }}+\beta_{L} \mathbb{E}\left[(1-\lambda) V_{L}^{\text {def }}\left(s^{\prime}, b_{r f}^{\prime}, 0\right)+\right. \\
+\lambda\left(1-r e l^{\prime}\right) V_{L}\left(s^{\prime}, b_{r f}^{\prime}, 0\right) \\
\left.+\operatorname{rel}^{\prime} V_{L}^{r e l}\left(s^{\prime}, b_{r f}^{\prime}, 0\right)\right], \\
\text { s.t. } c_{L}^{\text {def }}=\left(1+r^{r f}\right) b_{r f}-b_{r f}^{\prime} .
\end{gathered}
$$

Where equation (17) is investors' budget constraint, $V_{L}$ is the value function of the international investor when the government has access to financial markets, and $V_{L}^{r e l}$ is the policy 
function of the international investor when the government activates the hurricane clause. ${ }^{28}$ $\lambda$ is the probability of re-entry from autarky.

When the government has activated the hurricane clause, investors' value function becomes:

$$
\begin{gathered}
V_{L}^{r e l}\left(s, b_{r f}, b\right)=\max _{c_{L}^{r e l}, b_{r f}^{\prime}, b} c_{L}^{r e l}+\beta_{L} \mathbb{E}\left[c^{\prime, r e l}+\beta_{L} \mathbb{E}\left[V_{L}\left(s^{\prime \prime}, b_{r f}^{\prime \prime}, b_{L}^{\prime \prime}\right)\right]\right], \\
\text { s.t. } c_{L}^{r e l}=\left(1+r^{r f}\right) b_{r f}-b_{r f}^{\prime} . \\
\text { s.t. } c_{L}^{\prime, r e l}=\left(1-d^{\prime}-r e l^{\prime}\right)\left(b-q^{\prime \prime}\left(b_{L}^{\prime \prime}-(1-\psi) b\right)\right)+\left(1+r^{r f}\right) b_{r f}^{\prime}-b_{r f}^{\prime \prime} .
\end{gathered}
$$

Equation (19) is the resource constraint of the economy in the period in which the governments activates the disaster clause and it dictates that consumption equals income. Equation (20) is the resource constraint of the economy in the period in which the government resumes servicing debt. Consumption equals income plus net borrowing from abroad. Of note, outstanding debt levels $b$ are those inherited from the period before the activation of the disaster clause.

Finally, when the government has access to financial markets and has not activated the hurricane clause, the value function of investors is:

$$
\begin{gathered}
V_{L}\left(s, b_{r f,}, b\right)=\max _{c_{L}, b_{r f}^{\prime}, b} c_{L}+\beta_{L} \mathbb{E}\left[\left(1-d e f^{\prime}-r e l^{\prime}\right) V_{L}\left(s^{\prime}, b_{r f,}^{\prime}, b_{L}^{\prime}\right)+\operatorname{def}^{\prime} V_{L}^{\text {def }}\left(s^{\prime}, b_{r f,}^{\prime}, 0\right)\right. \\
\left.+\operatorname{rel}^{\prime} V_{L}^{r e l}\left(s^{\prime}, b_{r f}^{\prime}, b_{L}^{\prime}\right)\right], \\
\text { s.t. } c_{L}=\left(b-q\left(b_{L}^{\prime}-(1-\psi) b\right)\right)+\left(1+r^{r f}\right) b_{r f}-b_{r f}^{\prime} .
\end{gathered}
$$

The first-order conditions of the investors' maximization problem, when the government has access to financial markets are:

$$
\begin{array}{r}
b_{r f}^{\prime}: 1=\beta_{L} \mathbb{E}\left[\left(1-d e f^{\prime}-r e l^{\prime}\right) V_{b_{r f}, L}\left(s^{\prime}, b_{r f,}^{\prime}, b_{L}^{\prime}\right)\right. \\
+\operatorname{def}^{\prime} V_{b_{r f}, L}^{\text {def }}\left(s^{\prime}, b_{r f}^{\prime}, 0\right) \\
\left.+\operatorname{rel}^{\prime} V_{b_{r f}, L}^{r e l}\left(s^{\prime}, b_{r f,}^{\prime}, b_{L}^{\prime}\right)\right] \\
b^{\prime}: q=\beta_{L} \mathbb{E}\left[\left(1-d e f^{\prime}-r e l^{\prime}\right) V_{b, L}\left(s^{\prime}, b_{r f,}^{\prime}, b_{L}^{\prime}\right)\right. \\
+\operatorname{def}^{\prime} V_{b, L}^{\operatorname{def}}\left(s^{\prime}, b_{r f,}^{\prime}, 0\right) \\
\left.+r e l^{\prime} V_{b, L}^{r e l}\left(s^{\prime}, b_{r f,}^{\prime}, b_{L}^{\prime}\right)\right] .
\end{array}
$$

\footnotetext{
${ }^{28}$ In the continuation value I do not consider the case in which governments default in the same periods in which they are readmitted to international financial markets because this never happens in equilibrium.
} 
And:

$$
\begin{gathered}
V_{b_{r f}, L}=\left(1+r^{r f}\right) ; \\
V_{b_{r f}, L}^{d e f}=\left(1+r^{r f}\right) ; \\
V_{b_{r f}, L}^{r e l}=\left(1+r^{r f}\right) ; \\
V_{b_{L}, L}=1+q(1-\psi) ; \\
V_{b_{L}, L}^{\text {def }}=0 ; \\
\left.V_{b_{L}, L}^{r e l}=\beta_{L} \mathbb{E}\left[\left(1-d e f^{\prime}-r e l^{\prime}\right)+(1-\psi)\left(1-d e f^{\prime}-r e l^{\prime}\right) q^{\prime}\right)\right] .
\end{gathered}
$$

Plugging equations (25), (26), and (27) in (23), I obtain:

$$
\beta=\frac{1}{1+r_{r f}}
$$

Plugging equations (28), (29), (30), and (31) in (24), I obtain:

$$
\begin{array}{r}
q=\frac{1}{\left(1+r^{f}\right)} E\left[\left(1-d^{\prime}-r e l^{\prime}\right)+(1-\psi)\left(1-d^{\prime}-r e l^{\prime}\right) q^{\prime}\right. \\
\left.+\frac{r e l^{\prime}}{\left(1+r^{f}\right)} E\left[\left(1-d^{\prime \prime}-r e l^{\prime \prime}\right)+(1-\psi)\left(1-d^{\prime \prime}-r e l^{\prime \prime}\right) q^{\prime \prime} \mid y^{\prime}\right] \mid y\right] .
\end{array}
$$

First order condition (32) equates the marginal cost $q$ of purchasing government bonds to their marginal expected utility. Two factors determine investors' marginal utility associated with purchasing government debt. First, the expected utility investors receive next period if the government does not default and the hurricane clause is not triggered. Second, the utility that investors expect to receive in two-period time if the hurricane clause is triggered. 


\subsection{Debt Limits}

\section{Model}

In the economy with the debt limit, the government still faces three options: repay, default, or activate the hurricane clause. The optimal default and debt-servicing relief decisions solve:

$$
V=\max _{d, r e l}\left\{\xi\left((1-d-r e l) V^{n d}+r e l V^{r e l}+d V^{d}\right)+(1-\xi)\left((1-d) V^{n d}+d V^{d}\right)\right\} .
$$

Where $V^{n d}, V^{r e l}$ and $V^{d}$ are respectively the value functions when the government decides to repay, activate the hurricane clause, and default. $V^{\text {rel }}$ is solution to problem (11) that I presented in Section 6.1. $V^{d}$ is solution to problem (6) defined in Section 3. Finally, $V^{n d}$ solves:

$$
\begin{gathered}
V^{n d}(y, h, b,)=\max _{c, b^{\prime}} u(c)+\beta \mathbb{E}\left[V\left(y^{\prime}, h^{\prime}, b^{\prime}\right)\right] \\
\text { s.t. } c=y+q\left[b^{\prime}-(1-\psi) b\right]-b, \\
b^{\prime} \leq b^{*}(y, h, b,) \\
q\left(y^{\prime}, h^{\prime}, b^{\prime}\right)=\frac{1}{\left(1+r^{f}\right)} E\left[\left(1-d^{\prime}-r e l^{\prime}\right)+(1-\psi)\left(1-d^{\prime}-r e l^{\prime}\right) q^{\prime}\right. \\
\left.+\frac{r e l^{\prime}}{\left(1+r^{f}\right)} E\left[\left(1-d^{\prime \prime}-r e l^{\prime \prime}\right)+(1-\psi)\left(1-d^{\prime \prime}-r e l^{\prime \prime}\right) q^{\prime \prime} \mid y^{\prime}\right] \mid y\right] .
\end{gathered}
$$

Maximization problem (34)-(37) only differs from the maximization problem (2)- (24) because of the extra constraint $(36)$. Let $b^{*}(y, h, b$,$) be the equilibrium borrowing rule in the$ economy without the disaster clauses. Constraint (36), therefore prescribes that governments cannot issue more debt than in the economy without the disaster clauses. 


\section{Quantitative Analysis}

Table 8. Debt Limits

Panel A: Debt Limits and Disaster Clauses

\begin{tabular}{lccccccc}
\hline \hline Moment & Antigua & Belize & Dominica & Dominican Rep. & Grenada & Honduras & Jamaica \\
\hline \hline Average Spread & 462 & 123 & 327 & 482 & 466 & 367 & 506 \\
Ext. Debt/GDP ratio & 0.37 & 0.67 & 0.56 & 0.25 & 0.53 & 0.34 & 0.49 \\
\hline \hline & \multicolumn{7}{c}{ Panel B: Debt Limits and Disaster Clauses - Climate Change Scenario } \\
\multicolumn{1}{c}{ Antigua } & Belize & Dominica & Dominican Rep. & Grenada & Honduras & Jamaica \\
\hline \hline Moment & 642 & 220 & 436 & 563 & 548 & 502 & 632 \\
\hline \hline Average Spread & 0.33 & 0.44 & 0.58 & 0.24 & 0.51 & 0.33 & 0.47 \\
Ext. Debt/GDP ratio &
\end{tabular}

Panel A reports moments obtained simulating the model economies with debt limits and hurricane clauses for 9,500 periods. Panel B reports moments obtained simulating the model economies with the hurricane clause and debt limits in the climate change scenario which features a $29.2 \%$ increase of the frequency of hurricane and a $48.5 \%$ increase in the intensity of hurricanes.

Table 8 reports key moments for the economy with both disaster clauses and debt limits. In Panel A I report key moments obtained in the scenario without climate change. The comparison with Panel B of Table 2 shows that debt-to-GDP ratios are about the same in the two economies. Spreads, however, are lower in the economy with debt limits and disaster clauses. The comparison between Panel B of Table 8 and Panel A of Table 3 shows that the same is true in the climate change scenario. The stability of debt-to-GDP ratios follows by construction from the debt limits. The decline of government spreads follows from the fact that disaster clauses improve governments' borrowing term, as reported in Figure 2.

\subsection{Solution Algorithm}

For the baseline economy:

1. Discretize income processes $y$ and determine the transition matrix $Y^{\prime} \mid Y$ using the quadrature method for the normal distribution described in Tauchen and Hussey (1991)

2. Set up the grid of states $\Omega=\{y \times h \times b\}$ and choices $\left\{b^{\prime}\right\}$ 
3. Guess an arbitrary price $q$ for government bonds

4. Guess initial values for the vale functions $V^{n d}$ and $V^{d}$

5. Compute utilities and continuation values on each point of the grid

6. Iterate value functions till convergence

7. Update the price of government debt according to equation (24)

8. Repeat steps (4)-(7) until the price of government debt has converged.

For the economy with the disaster clause:

1. Discretize income processes $y$ and determine the transition matrix $Y^{\prime} \mid Y$ using the quadrature method for the normal distribution described in Tauchen and Hussey (1991)

2. Compute the transition matrix $Y^{\prime \prime} \mid Y$ where $y^{\prime \prime}\left|y_{i j}=Y^{\prime}\right| Y(i,:) * Y^{\prime} \mid Y(:, j)$

3. Set up the grid of states $\Omega=\{y \times h \times b\}$ and choices $\left\{b^{\prime}\right\}$

4. Guess an arbitrary price $q$ for government bonds

5. Guess initial values for the vale functions $V^{n d}$ and $V^{d}$

6. Compute utilities and continuation values on each point of the grid

7. Iterate value functions till convergence

8. Update the price of government debt according to equation (13)

9. Repeat steps (5)-(8) until the price of government debt has converged. 